\title{
Characterization of Depuration Process of Mytilus galloprovincialis in Presence of Chloramine-T and Super-Oxidized Water ${ }^{\#}$
}

\author{
İbrahim Ender Künili1,a,*, Fatma Çolakoğlu²,b \\ ${ }^{1}$ Department of Fishing and Processing Technology, Faculty of Marine Sciences and Technology, Çanakkale Onsekiz Mart University, \\ 17100 Çanakkale, Turkey \\ ${ }^{2}$ School of Applied Sciences, Çanakkale Onsekiz Mart University, 17100 Çanakkale, Turkey.
}

*Corresponding author

\begin{tabular}{|c|c|}
\hline A R T I C L E I N F O & A B S T R A C T \\
\hline $\begin{array}{l}\text { "This study was presented as an oral } \\
\text { presentation at the 4th International } \\
\text { Anatolian Agriculture, Food, } \\
\text { Environment and Biology Congress } \\
\text { (Afyonkarahisar, TARGID 2019) } \\
\text { Research Article }\end{array}$ & $\begin{array}{l}\text { Seafood poisoning due to mussels contaminated with pathogens is an important health issue all over } \\
\text { the world. Increasing attention and efforts are made to improve the last product quality of mussels } \\
\text { and to save consumers from food poisoning. In this study, the depuration process of black mussels } \\
\text { (Mytilus galloprovincialis) which have a high consumption rate and located in coastal waters of } \\
\text { Turkey was tried to improve using Chloramine-T and superoxide disinfectants. For this purpose, } \\
\text { mussels contaminated with Escherichia coli were subjected to depuration for } 6 \text { hours in the presence } \\
\text { of } 20 \mathrm{mg} / \mathrm{L} \text { of two disinfectants. In the study, It was determined that } E \text {. coli numbers in the mussels } \\
\text { of disinfectant groups with an initial bacterial load of } 4.4 \text { Log cfu / g, decreased to } 3.70 \text { and } 3.86 \\
\text { Log cfu / g, respectively and the depuration was faster than the control group ( } 4.05 \text { Log cfu / g). As } \\
\text { a result, it has been concluded that the use of food-suitable disinfectants in deposition waters can be } \\
\text { used for faster and more effective purification. However, considering the possibility of chemicals } \\
\text { leaving residues in mussels, detailed studies should be carried out. }\end{array}$ \\
\hline
\end{tabular}

Chloramine-T

Depuration

Escherichia coli

Mytilus galloprovincialis

Super-oxidized water

enderkunili@yahoo.com

\section{Introduction}

Shellfish are very popular food and their consumption continues to rise globally. Mytilus galloprovincialis is one of the most important shellfish species traded and consumed in Turkey. Because of their unique nature, shellfish have their own distinct aspects. They are filterfeeding organisms that can accumulate human pathogenic bacteria, when grown in sewage-polluted or contaminated waters. Therefore, shellfish quality and safety is critical for protecting public health. Controlled self-purification (depuration) of shellfish is a common practice that is utilized to reduce loads of microorganisms. It is done in controlled seawater of which temperature, salinity, oxygenation, and flow rate are monitored permanently. Additionally, in these systems, the seawater should also be cleaned and disinfected by various treatments such as chlorine, UV light, ozone, activated oxygen, iodophor and filtrations to achieve successful depuration of shellfishes.
Disinfectants play an essential role in the prevention and control of harmful bacteria. There are also various disinfectants that have been recommended for the disinfection of water in recent years. Several disinfectants are available in the market such as quaternary ammonium compounds, glutaraldehyde, ethylic alcohol, super oxidized solutions, povidone iodine, and chlorhexidine. Among these, chloramine-T and super oxidized solutions are disinfectants capable of destroying bacteria, fungi, viruses, and spores through different mechanisms of action. The most common usage in general is as disinfectant or sanitation agent in the food, beverage, poultry, and dairy products industries. It has also been used for the prevention of some bacterial disease in aquaculture.

Depuration process of bivalves with presence of such disinfectant substances in the literature is limited. Addition of these substances to depuration tanks may help to 
bivalves in terms of excreting microorganisms in shorter times. Improvement in depuration rate of shellfish with effective and safer ways is important issue to help producers and countries for faster production and proper trade, along with saving consumers from the health risks.

For this reason, in this study, it was aimed to determine an effective way to depuration of Mytilus galloprovincialis with using super-oxidized water and chloramine-T in the depuration water. In addition to chemical disinfectants aided depuration process in short term, standard depuration procedure described by European Commission and Turkish Legislations were performed to experimentally contaminated Mytilus galloprovincialis. Results were compared with standard depuration processes in order to determine the effectiveness of addition chemicals to depuration systems.

\section{Material and Methods}

\section{Material}

Total of $50 \mathrm{~kg}$ depurated Mytilus galloprovincialis, were supplied from an aquaculture facility located at the Southern Coast of Marmara Sea, Turkey. Mean height and weight of samples were measured as $12.47 \pm 1.14 \mathrm{~g}$ and $80.76 \pm 5.44 \mathrm{~mm}$, respectively. Samples were then packaged with mesh wire bags and replaced with ice for transport.

\section{Preparation of Bacterial Strain}

Lyophilized Escherichia coli ATCC 25922 (American Type Culture Collection, USA) strain was used in trials. Before using the strain, overnight culture was prepared in Muller Hinton Broth at $35^{\circ} \mathrm{C}$. Prior contamination, bacterial peptone water $(1 \% \mathrm{w} / \mathrm{v})$ and salt $(8.5 \% \mathrm{w} / \mathrm{v})$ was used to prepare decimal dilutions. McFarland meter (Biosan, Den1) was used for last point bacterial load of peptone waters which were used in contamination tanks for loading mussels with $E$. coli.

\section{Minimum Inhibition Concentrations}

Commercial chloramine-T (Halamid $®$ ) and superoxidized water (food environment grade, purchased from a local food hygiene supplier) were used for experiments. In order to determine the minimum inhibition concentrations (MIC) of these additives against E. coli, $10 \mathrm{ppm}$ to $50 \mathrm{ppm}$ concentrations were tested according to 96 well-plate microdilution method (Devienne \& Raddi, 2002). Incubation at $35^{\circ} \mathrm{C}$ and reading at $630 \mathrm{~nm}$ of the inoculated plates were performed with ELISA reader (Thermo). Predetermined MICs of the additives that are effective at least as bacteriostatic effect were chosen as center concentrations for using in depuration process of mussels.

\section{Acclimation of the Mussels}

Prior to the experiment, the mussels were acclimatized for $6 \mathrm{~h}$ in tanks containing 500 liters of seawater to confirm that specimens were alive and actively filtering. The conditions in the acclimation tanks were; salinity 2.9-3.2\%; temperature $12-14^{\circ} \mathrm{C}$; oxygen values $>90 \%$ of air saturation, measured using a Dissolved Oxygen Meter YSI 58.

\section{Contamination of Mussel Samples}

Total of samples were divided into three groups. While one of them represents control group, others were for chloramine-T and super oxidized water. All of these groups were contaminated with the prepared E. coli strain (ATCC 25922) at the level of $4.4 \mathrm{Log} \mathrm{cfu} / \mathrm{g}$ (meat and intervalvular liquid). Contamination procedure was maintained in $100 \mathrm{~L}$ polyethylene tanks filled with clean seawater. Prepared E.coli cocktails found in peptone waters were then added to these tanks. Then, the contaminated mussels were collected from the tanks after 30 min contamination process.

\section{Depuration of Mussels}

Depuration process of mussels was carried out under the controlled physicochemical conditions using commercial oval baths (diameter, $1.5 \mathrm{~m}$; depth of water, $1.0 \mathrm{~m}$ ). The system, with an open-circuit seawaterdisinfection system that uses both mechanical and biological filtrations fortified with UV filter. In the tanks, water parameters were monitored and controlled to produce a 'standard conditioned seawater' of 18 parts per thousand (ppt) salinity, $\mathrm{pH} 7.0-7.3$, and 6.5 to $7.1 \mathrm{mg} / \mathrm{l}$ of dissolved oxygen (DO). DO levels were compared, though levels were maintained and monitored with a DO meter. DO of $5 \mathrm{mg} / \mathrm{l}$ is the lower limit recommended for depuration, and $7 \mathrm{mg} / \mathrm{l}$ is the approximate solubility limit of oxygen in seawater having $18 \mathrm{ppm}$ salinity at $14^{\circ} \mathrm{C}$. The mussels were placed on the ground of tanks by one by and they were removed for microbiological analysis at $0,1^{\text {th }}$, $2^{\text {th }}, 3^{\text {th }}, 4^{\text {th }}, 5^{\text {th }}$, and $6^{\text {th }}$ hours of depuration process. Each experiment was carried out in triplicate.

\section{Microbiological Analysis of Mussels}

Microbiological analysis of samples was performed according to the method described by Çolakoğlu et al. (2014). Briefly, mussels were washed and scrubbed free of dirt. Samples then were scrubbed with a sterile knife, and microbial groups were enumerated using the plate count method as described by the Food and Drug Administration (FDA, 1998). The surfaces of the samples were cleaned with alcohol. Meat and intervalvular liquid of samples (a total of $10 \mathrm{~g}$ ) was diluted in $90 \mathrm{ml}$ physiological saline solution (peptone water). Samples were removed in sterile stomacher bags and homogenized in Stomacher 400 Circulator (Seward, UK) for 2 minutes at low speed. The homogenates of samples were subjected to a series of serial dilutions with physiological saline solution. Standard plate count method with using ENDO Agar (Merck) was used for enumeration $E$. coli in samples. Total of 24 and 48 hours incubation at $37^{\circ} \mathrm{C}$ was used for growth of E. coli. After incubation, typical $E$. coli colonies were count and the results expressed as Log cfu/g of sample.

\section{Statistical Analyses}

Descriptive statistics (mean and standard deviation) for quantitative variables, such as length, weight of mussels, and levels of bacteria; and $\mathrm{T}$ test for determining the depuration ability of the mussels for $E$. coli in the presence of Chloramine-T and super oxidized water were performed with using Microsoft Office Excel 2007 software (Seattle, USA). 


\section{Results and Discussion}

Present study was designed and performed to find a way to prevent both consumers from health risks due to consume inadequately handled bivalves and producers from the time lost and increasing of work-load originated from prolonged depuration times. In the scope of this study, it was determined the short-term depuration conditions of mussels contaminated with $E$. coli in the presence of Chloramine-T and super-oxidized water. The concentrations of both substances used in depuration waters were determined after antimicrobial tests performed against $E$. coli in laboratory. The results of antimicrobial test of the substances were given in Figure 1.

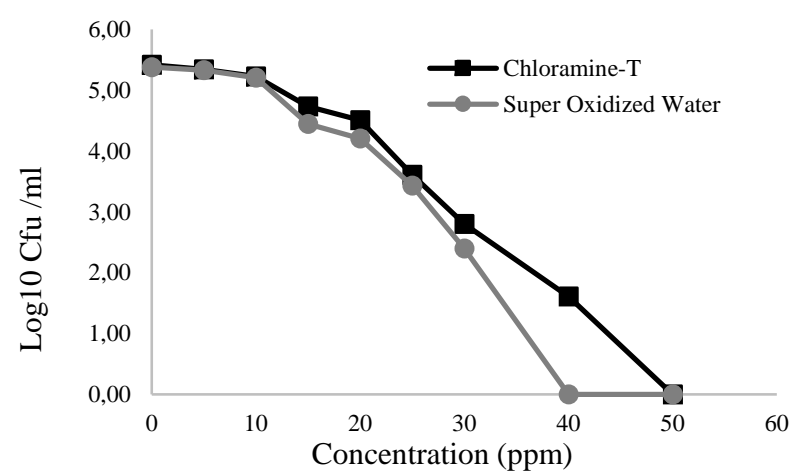

Figure 1 Antimicrobial and bacteriostatic effects of Chloramine-T and Super Oxidized Water against Escherichia coli

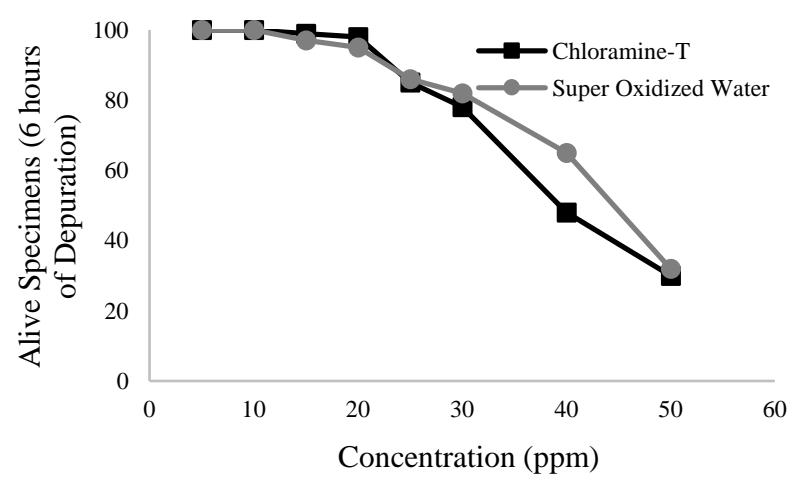

Figure 2 Alive mussel specimens (\%) after six hours of depuration in the presence of Chloramine-T and super oxidized water $(n=100)$

Before depuration of mussels, minimum inhibition concentrations of Chloramine-T and super oxidized water were determined in order to use exact amount of these substances. The 20 ppm concentration for both substances was selected for trials, since the raising in concentration above the 20 ppm caused to death of mussels (Figure 2). Moreover, using higher concentrations of Chloramine-T and super oxidized water was not considered that may lead improper food safety issues. Chloramine-T and superoxidized water have shown bacteriostatic effect to the $E$. coli strains used in trials at the concentrations of 10 to 20 ppm. Antibacterial effect was observed after $20 \mathrm{ppm}$ concentration for both substances. For this reason, $20 \mathrm{ppm}$ for both substances was selected as standard concentration to enhance the depuration rates of M. galloprovincialis contaminated with $E$. coli.
Super oxidized water is an alternative disinfectant to traditional chemical ones. It has a strong and wide range disinfectant effect which is made by electrolyzing the solutions of $\mathrm{NaCl}, \mathrm{KCl}$ or $\mathrm{MgCl}_{2}$ (Achiwa et al., 2003). Super oxidized water is considered safer than chemical disinfectants due to using $\mathrm{NaCl}$ and tap water for its production and getting normalize when diluted in water. For this reason, it can be widely used in food, medical and agricultural industries (Achiwa et al., 2003, Fujiwara et al., 2000, Park et al., 2002a, Park et al., 2002b, Shiba et al., 2000, Takahashi et al., 2002, Yoshida et al., 2003). Using super oxidized water as a disinfectant at different surfaces has been well documented in literature (Venkitanarayanan et al., 1999; Al-Haq et al., 2001; Kim et al., 2001., Fabrizio et al., 2002; Kim et al., 2003; Liao et al., 2007; . Among the studies, seafood related studies which deal with various microorganisms such as, E. coli, L. monocytogenes, Salmonella sp., and some viruses can be found in literature; however, studies on using super oxidized water in deputation process of shellfish is very limited.

Chlorine is well known disinfectant which is used in waters for years. On the other hand, Chloramine-T is a water soluble chemical that hypochlorite ions form when it is dissolved in water (MacDonald 1988). The disinfection process occurs with oxidization via strong oxidation potential of hypochlorite ions and changed ion equals (Booth and McDonald 1988). Oxidation process in the presence of Chloramine-T occurs with destroying the cellular material and cell process, and microorganism do not develop resistance to this overtime process (Powell and Clark, 2003; Bowker et al., 2011). In general, it was proved that Chloramine-T at low concentration is a chemical that does not release residue and effective in biological environment (Roosenburg et al., 1980; Salvesen and Vadstein, 1995; Subagja et al. 1999). Altinok (2004) has reported that the toxicity and therapeutic effects of Chloramine-T for treating Flavobacterium columnare infection of goldfish. It was concluded by the researcher that the $15 \mathrm{mg} / \mathrm{ml}$ concentration for treating the $F$. columnare infected goldfishes with Chloramine-T was applicable in experimental conditions (Altinok, 2004). Bowker et al. (2011) have reported that the $20 \mathrm{mg} / \mathrm{l}$ concentration of Chloramine-T application for therapeutic purpose to rainbow trout fry, fingerlings, or juveniles for $60 \mathrm{~min} /$ day is safe with $100 \%$ survival rate.

Contamination mussels with $E$. coli at the concentration of $4.4 \mathrm{Log} \mathrm{cfu} / \mathrm{g}$ was a purpose to meet the EU Legislations for threshold levels of inconsumable mussels (Class C, need long time depuration process before trade or consume). For this reason, we tried to adjust the $E$. coli concentrations in previously depurated mussel samples as $4.4 \mathrm{Log} \mathrm{cfu} / \mathrm{g}$. In the results of the present study, the level of E.coli was determined as $4.5 \mathrm{Log} \mathrm{cfu} / \mathrm{ml}$ in the water found in contamination tank and 4.3-4.4 Log cfu/g in mussels. After starting depuration, the process microbiologically controlled at every hour with analyzing the mussels found in the depuration tank (filled clean seawater with chloramine- $\mathrm{T}$ and super-oxidized water). There was no rapid decrease detected in all groups, however depuration with Chloramine-T and superoxidized water was slightly faster than the control group. In first hour of trial, excreting E.coli from mussels was nearly 1 Log in both treatments, while control group 
remains nearly same. After the first hour, regular decreases were observed in all groups. The slight differences in both trials in comparison with the control group, continued to the end of experiment. After 3 hours of depuration of mussels, E. coli remained in control, Chloramine-T, and super-oxidized water as $4.25,4.11$, and $4.15 \mathrm{Log} \mathrm{cfu} / \mathrm{g}$ respectively. And the last hour of depuration (after 360 min), the levels of E.coli was detected as 4.05, 3.70, and $3.86 \mathrm{Log} \mathrm{cfu} / \mathrm{g}$ for control, chloramine-T, and superoxidized water, respectively.

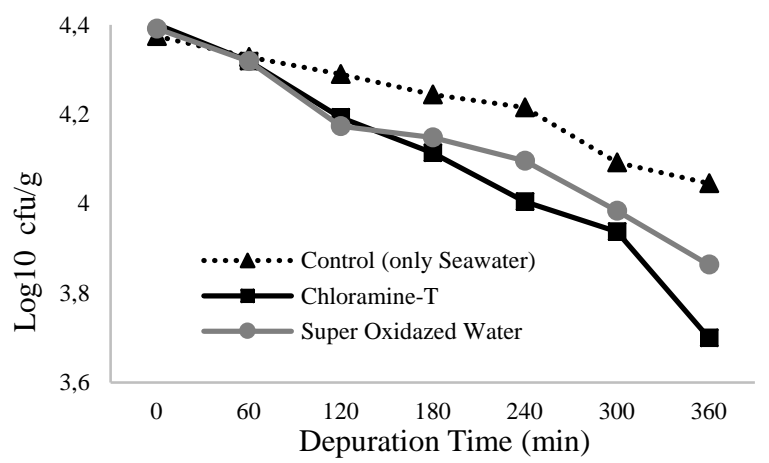

Figure 3 Depuration times of Mytilus galloprovincialis contaminated with $E$. coli in the standard depuration system, in the presence of Chloramine-T, and Super Oxidized Water (20 ppm concentration)

Contamination of shellfishes via marine water by $E$. coli is mainly due to the disposal of wastewater and it indicates the possible presence of pathogenic microorganisms. Therefore, E. coli concentrations are recognized as a shellfish quality indicator by international regulations. The present study has shown that mussels contaminated with $E$. coli at the concentration $4.4 \mathrm{Log} \mathrm{cfu} / \mathrm{g}$ which is the threshold level of European Legislation classification for Class C quality shellfishes, can have faster depuration rates in comparison with control depuration process in six hours. Longer depuration times were not the aim of this study, since this subject was well documented in standard depuration systems by researchers (Çolakoğlu et. al. 2012).

As a consequence, results of this study have shown that Chloramine-T and super-oxidized water may have been used for shortened depuration times in comparison with standard depuration process. Although it was considered that the usage of Chloramine-T and super-oxidized water in food environments are safe, further research is still needed to determine the time of accumulation and release of chlorine substances in mussels in order to ensure food safety. Moreover, alternative ways or additive substances should be investigated for faster and reliable depuration process of $E$. coli or other microorganisms, such as viruses, parasites, and pathogen bacteria to obtain safer products.

\section{References}

Achiwa N, Katayose M, Abe K. 2003. Efficacy of electrolyzed acidic water for disinfection and quality maintenance of fresh-cut cabbage. Food Preserv. Sci., 29: 341-346.

Altinok I. 2004. Toxicity and therapeutic effects of chloramine-T for treating Flavobacterium columnare infection of goldfish. Aquaculture. 239: 47-56.

Al-Haq MI, Seo Y, Oshita S, Kawagoe Y. 2001. Fungicidal effectiveness of electrolyzed oxidizing water on postharvest brown rot of peach. HortScience, 36, 1310-1314.
Booth NH, McDonald LE. 1988. Veterinary pharmacology and therapeutics, 6th edition. Iowa State University Press, Ames.

Bowker JD, Carty D. 2011. Chloramine-T Margin of Safety Estimates for Fry, Fingerling, and Juvenile Rainbow Trout. N Am J Aquac., 73: 259-269.

CLSI. 2006. Performance standards for antimicrobial disk susceptibility tests. Approved standard. 9th Edition Document M2-A9. Clinical and Laboratory Standards Institute, Wayne, PA.

Çolakolu FA, Çardak M, Çolakoglu S, Künili IE. 2014. Depuration Times of Donax trunculus and Tapes decussatus. Braz J. Microbiol., 45:1017-1022.

Devienne KF, Raddi MSG. 2002. Screening for Antimicrobial Activity of Natural Products Using a Microplate Photometer. Braz J. Microbiol., 33: 166-168.

European Commission 1991. Council Directive 91/492 of 15 July 1991 laying down the health conditions for the production and the placing on the market of live bivalve molluscs. Official Journal of the European Communities 268:1-14.

Fabrizio KA, Sharma RR, Demirci A, Cutter CN. 2002. Comparison of electrolyzed oxidizing water with various antimicrobial interventions to reduce Salmonella species on poultry. Poultry Science, 81, 1598-1605.

Fujiwara K, Doi R, Iimoto M, Fujii T. 2000. Fundamental studies on crop disease control by spraying electrolyzed anode-side water. Environ. Control Biol., 38: 263-271.

Kim C, Hung YC, Brackett RE, Frank JF. 2001. Inactivation of Listeria monocytogenes biofilms by electrolyzed oxidizing water. J Food Process and Preserv., 25: 91-100.

Kim C, Hung YC, Brackett RE, Lin CS. 2003. Efficacy of electrolyzed oxidizing water in inactivating Salmonella on alfalfa seeds and sprouts. J Food Protect., 66: 208-214.

Liao L, Chen WM, Xiao XM. 2007. The generation and inactivation mechanism of oxidation-reduction potential of electrolyzed oxidizing water. J Food Eng., 1326-1332.

Park H, Hung Y, Brackett R. 2002a. Antimicrobial effect of electrolyzed water for inactivating Campylobacter jejuni during poultry washing. Food Microbiol., 72: 77-83.

Park H, Hung Y, Kim C. 2002b. Effectiveness of electrolyzed water as a sanitizer for treating different surfaces. J. Food Prot., 65: 1276-1280.

Powell MD, Clark, GA. 2003. In vitro survival and the effect of water chemistry and oxidative chemical treatments on isolated gill amoebae from AGD-affected Atlantic salmon. Aquaculture. 220:135-144.

Roosenburg WH, Rhoderick JC, Block RM, Kennedy VS, Gull SR, Vreenegoor SM, Rosenkranz A. Collette C. 1980. Effects of Chlorine-Produced Oxidants on Survival of Larvae of the Oyster Crassostrea virginica. Mar. Ecol. Prog. Ser., 3: 93-96.

Shiba A, Tsukasaki H, Kanaishi A, Shiba K, Chida T, Okamura N. 2000. Electrolyzed strong acidic water as a new harmless disinfectant agent and its application to dentistry. J. Showa Univ. Dent. Soc., 20:173-179.

Subagja J, Slembrouck J, Hung LT, Legendre M. 1999. Larval rearing of an Asian catfish Pangasius hypophthalmus (Siluroidei, Pangasiidae): Analysis of precocious mortality and proposition of appropriate treatments. Aquat. Living Resour., 12:37-44.

Salvesen I, Vadstein O. 1995. Surface disinfection of eggs from marine fish: evaluation of four chemicals. Aquaculture International., 3: 155-171.

Takahashi Y, Takeshita A, Endo M, Sasaki M. 2002. Cleaning effectiveness of electrolyzed water depending on the nursing procedure and degree of hand contamination. Biocontrol Sci., 7: 173-179.

Venkitanarayanan KS, Ezeike GOI, Hung YC, Doyle MP. 1999. Inactivation of Escherichia coli $\mathrm{O} 157: \mathrm{H} 7$ and Listeria monocytogenes on plastic kitchen cutting boards by electrolyzed oxidizing water. J Food Protect., 62, 857-860.

Yoshida K, Min J, Park J, Isobe S, Suzuki T. 2003. Disinfecting rice seeds using acidic electrolyzed water. Nogyo Shisetsu, 33: $247-253$. 